DOI: $10.15593 / 2224-9982 / 2019.56 .06$

УДК 676.163 .5

\author{
Ф.Х. Хакимова, О.А. Носкова, С.А. Котельников, К.А. Синяев
}

Пермский национальный исследовательский политехнический университет, Пермь, Россия

\author{
ПОЛУЧЕНИЕ ПРИРОДНОГО ПОЛИМЕРНОГО МАТЕРИАЛА \\ ДЛЯ ИСПОЛЬЗОВАНИЯ В ЭНЕРГОНАСЫЩЕННЫХ КОМПОЗИЦИЯХ
}

\begin{abstract}
Разработана технология получения древесной растворимой целлюлозы для химической переработки (нитрования). Получены условия сульфитной варки еловой промышленной щепы с образованием целлюлозы глубокой степени провара и необходимой вязкости при возможно минимальной гидролитической деструкции углеводной части древесины.

Разработаны условия всех стадий получения целлюлозы - варки, отбелки, облагораживания. Получена необычная оригинальная технология отбелки и облагораживания целлюлозы со следующими особенностями. В соответствии с современными требованиями получена исключительно экологичная технология отбелки целлюлозы без использования хлора и хлорсодержащих реагентов - технология TCF. Предлагается отбелка целлюлозы без кислорода и озона, широко используемых в настоящее время в TCF-технологиях, так как применение их усложняет технологию и процессы отбелки. В результате получена уникальная укороченная технология с использованием на стадиях делигнификации и отбелки целлюлозы всего одного окислительного реагента - пероксида водорода в кислой среде с применением катализатора. Окончательная схема отбелки следующая: Пк - Щ -Пк - ГО - К.

Разработаны оптимальные условия каждой ступени обработки целлюлозы при отбелке и облагораживании, не вызывающие существенной деградации углеводной части целлюлозы.

В лабораторных условиях с воспроизведением всех стадий промышленного производства получена еловая сульфитная беленая и облагороженная целлюлоза, по всем показателям качества соответствующая требованиям к древесной целлюлозе ЦА марки К.

Таким образом, получена по оригинальной технологии древесная целлюлоза, по показателям качества не уступающая растворимой целлюлозе из хлопка, которая в настоящее время считается наилучшим сырьем для химической переработки.
\end{abstract}

Ключевые слова: древесная целлюлоза, сульфитная варка, отбелка, облагораживание, TCF-технология, пероксид водорода, нитрование.

\author{
F.H. Khakimova, O.A. Noskova, S.A. Kotelnikov, K.A. Sinyaev
}

Perm State National Research University, Perm, Russian Federation

\title{
PRODUCTION OF NATURAL POLYMER MATERIAL FOR USE IN ENERGY-SATURATED COMPOSITIONS
}

The production technology of dissolving pulp (for nitration) was developed. Conditions of sulfite pulp cooking of industrial spruce wood chips with obtaining pulp with low hardness and the desired viscosity with minimal hydrolytic degradation of the carbohydrate part of the wood were obtained.

Conditions of all pulp production stages were developed: cooking, bleaching and hot alkaline treatment (HAT). An unusual and original technology of pulp bleaching and alkaline treatment with the following features was obtained. In accordance with modern requirements, an extremely environmentally friendly TCF pulp bleaching technology was obtained. In particular, it is proposed to bleach pulp without oxygen and ozone, which are currently widely used in TCF technologies, since their application complicates the technology and bleaching processes. The result is a unique shortened technology with using only one oxidizing reagent (hydrogen peroxide with catalyst in acidic medium) at the stages of delignification and bleaching of pulp. The final scheme of bleaching: $\mathrm{Pa}_{1}-\mathrm{E}-\mathrm{Pa}_{2}-\mathrm{HAT}-\mathrm{A}$.

In laboratory with reproduction of all industrial production stages the sulfite bleached pulp and the dissolving pulp conforming to requirements of quality to $\mathrm{K}$ grade $\mathrm{CA}$ wood pulp was obtained.

Thus, according to the original technology, wood pulp was obtained, which is not inferior to cotton dissolving pulp in terms of quality, which is currently considered the best raw material for chemical processing.

Keywords: wooden pulp, sulfite cooking, bleaching, refining, TCF-technology, hydrogen peroxide, nitration. 


\section{Введение}

Целлюлоза является наиболее распространенным природным полимером и обладает рядом ценных свойств (высокая прочность, нетоксичность, биоразлагаемость, доступность), благодаря чему широко используется в различных отраслях промышленности - фармацевтической, медицинской, пищевой, целлюлозно-бумажной, текстильной, оборонной, а также является основой для получения наноматериалов [1,2].

Целлюлозно-бумажная промышленность вырабатывает волокнистую целлюлозу для различных нужд бумажного и картонного производства (из целлюлозы получают более 600 видов бумаги и картона), а также выпускает специальные виды целлюлозы, предназначенные для последующей химической переработки $[3,4]$. Такую целлюлозу используют для получения простых и сложных эфиров целлюлозы, на основе которых вырабатывают вискозные и ацетатные нити, высокопрочные кордные и штапельные волокна, целлофановые пленки, пластмассы, лаки, бездымный порох, кинопленку, изделия медицинского и гигиенического назначения [5].

Целлюлозу, которая применяется для химической переработки, называют растворимой, поскольку в процессе такой переработки получаемые эфиры и другие производные целлюлозы растворяют в различных растворителях с получением из этих растворов готового продукта. Для химической переработки используют исключительно беленую и большей частью облагороженную целлюлозу, имеющую строго определенные специфические свойства. Наиболее важными показателями являются высокое содержание $\alpha$-целлюлозы, минимальное содержание нецеллюлозных примесей (гемицеллюлоз, лигнина, экстрактивных веществ, минеральных веществ), равномерное молекулярно-массовое распределение, относительно невысокая степень полимеризации, небольшая вязкость растворов целлюлозы, высокая реакционная способность [5, 6].

Требуемые характеристики формируются в процессах варки, отбелки и облагораживания целлюлозы.

Наилучшим сырьем для химической переработки является хлопковая и древесная растворимая целлюлоза. В настоящее время производители эфиров целлюлозы столкнулись с проблемой сырьевого обеспечения. Хлопковая целлюлоза является импортируемым дорогостоящим и дефицитным сырьем и часто неудовлетворительного качества [7-9]. Производство древесной растворимой целлюлозы в промышленных масштабах в России приостановлено, тогда как в зарубежной практике получение такой целлюлозы востребовано и широко распространено, так как спрос на данный вид целлюлозы велик [10]. Широкий спектр продуктов, производимых из целлюлозы, определяет необходимость постоянного роста ее производства [11].

В частности, потребность в природном полимере - целлюлозе - испытывают производители нитратов целлюлозы. В настоящее время нитраты целлюлозы имеют широкий спектр использования - в косметике, красках, лаках, в качестве энергетического компонента в артиллерийском порохе и ракетном топливе [9].

Распад СССР, потеря «узбекского» хлопка заставляет искать замену высококачественному сырью, которое, например, успешно использовалось при производстве порохов на основе коллоксилина. Смена сырья приводит к необходимости проведения научно-исследовательских работ по получению целлюлозы, не уступающей по своим свойствам целлюлозе из хлопка. Задача эта имеет важное значение для производства пороха и оборонной промышленности.

Таким образом, актуальным является разработка современных технологий получения древесной целлюлозы для химической переработки и возобновление в России производства растворимой целлюлозы (в частности, для нитрования).

Однако в настоящее время к целлюлозно-бумажной промышленности предъявляются чрезвычайно высокие требования по охране окружающей среды. Основным участком, загрязняющим окружающую среду, является производство беленой целлюлозы, так как отбелка целлюлозы - наиболее загрязняющая окружающую среду стадия целлюлозного производства [5]. 
В мировой практике в настоящее время основное направление развития технологии производства целлюлозы - переход к отбелке ее без использования элементарного хлора (ЕСF Elemental Chlorine Free-технология) и без использования любых хлорсодержащих соединений (TCF - Total Chlorine Free-технология). Связано это с тем, что при традиционной отбелке с использованием хлора и хлорсодержащих реагентов образуется большое количество хлорорганических соединений в виде АОХ - адсорбируемых органических соединений хлора. Отбелка по ECF-технологии приводит к существенному снижению в сточных водах отбелки целлюлозы величины АОХ, а отбелка по ТСF-технологии исключает образование АОХ.

Целесообразность использования того или иного варианта оценивается, соответственно, не только по экологичности способа, но и с точки зрения экономичности схемы отбелки $[12,13]$. Отбелка без использования любых хлорсодержащих реагентов (ТCF) - наиболее дорогостоящая. Есть сведения о том, что себестоимость целлюлозы, полученной по технологии TCF, на 30-50 долл. выше по сравнению с технологией ЕCF с использованием диоксида хлоpa [14]. Однако сопоставление капитальных затрат показывает, что при строительстве нового целлюлозного завода отбелка ТСF оказывается более экономичной. При модернизации и расширении действующего завода переход к схемам отбелки ЕСF требует в 1,5-2 раза меньше инвестиций, чем переход на полностью бесхлорную отбелку [15].

Кроме того, в приведенных примерах (по экономичности) речь идет об отбелке целлюлозы для производства бумаги, т.е. целлюлозы с повышенным содержанием остаточного лигнина. При получении целлюлозы для химической переработки отбелке подвергается сульфитная целлюлоза глубокой степени провара с низким содержанием остаточного лигнина, в связи с чем варианты отбелки по ЕCF- и ТCF-технологиям по экономичности получаются сопоставимыми.

В настоящее время в области отбелки сульфитной вискозной целлюлозы наилучшей доступной технологией признана технология отбелки TCF. Практически все зарубежные производители сульфитной вискозной целлюлозы, за исключением некоторых предприятий ЮАР, перешли на эту технологию отбелки [10].

Сульфитная целлюлоза из еловой древесины до сих пор остается основным полуфабрикатом для получения растворимой целлюлозы для химической переработки. Этому способствует более высокий выход сульфитной мягкой целлюлозы, низкое содержание пентозанов, относительно легко удаляемых, большая равномерность по молекулярной массе.

При отбелке целлюлозы по современным ECF- и ТCF-технологиям большое значение приобретает использование пероксида водорода в отбелке целлюлозы. Известно, что пероксид водорода может быть использован в отбелке целлюлозы и как делигнифицирующий реагент и в щелочной, и в кислой среде [16-18], т.е. пероксид водорода является эффективным и делигнифицирующим, и отбеливающим реагентом. Таким образом, можно считать, что возможна отбелка целлюлозы по полной схеме с использованием одного окислительного реагента - пероксида водорода.

\section{Экспериментальная часть}

Задача работы состояла в разработке ТCF-технологии получения специальной древесной целлюлозы, предназначенной для химической переработки (растворимой целлюлозы). Требования к свойствам целлюлозы для химической переработки существенно отличаются от требований к показателям качества целлюлозы для получения бумаги.

При получении сульфитной целлюлозы для химической переработки в схеме отбелки обязательно используется горячее щелочное облагораживание, цели которого - повышение химической чистоты и молекулярной однородности, повышение содержания $\alpha$-целлюлозы, придание целлюлозе для химической переработки необходимой реакционной способности.

В процессе облагораживания происходит также изменение коллоидно-химических и физических свойств целлюлозы, определяющих поведение целлюлозы при получении ее производных. 
Получение целлюлозы включает две основные технологии - варку древесины с получением небеленой целлюлозы и отбелку целлюлозы, в которую включается и стадия облагораживания.

В наших исследованиях для получения растворимой целлюлозы использована «мягкая» сульфитная целлюлоза с невысокой долей остаточного лигнина, которую получали в лабораторных условиях варкой еловой древесины сульфитным способом.

Сырье для получения целлюлозы - промышленная щепа из древесины ели. Варки проведены в лабораторных автоклавах вместимостью 2 л с электрообогревом.

Варочную кислоту также получали в лабораторных условиях поглощением газа $\mathrm{SO}_{2}$ водопроводной водой.

Состав варочной кислоты, условия и результаты варки, характеристика небеленой целлюлозы приведены в табл. 1. Принятый график варки приведен на рис. 1.

Таблица 1

Условия и результаты сульфитных варок

\begin{tabular}{|c|c|c|c|}
\hline Условия варки & Значения & Результаты варок & $\begin{array}{c}\text { Величины } \\
\text { показателей }\end{array}$ \\
\hline $\begin{array}{l}\text { Состав варочной кислоты } \\
\text { Массовая доля в кислоте, \%: } \\
\text { - всего } \mathrm{SO}_{2} \\
\text { - связанного } \mathrm{SO}_{2} \text { (основания) } \\
\end{array}$ & $\begin{array}{c}8,2-8,4 \\
0,81-0,84 \\
\end{array}$ & \begin{tabular}{|l} 
Выход целлюлозы, \% от древесины: \\
- общий \\
- сучков и непровара \\
- целлюлозы \\
\end{tabular} & $\begin{array}{c}49,2 \\
1,2 \\
48,0 \\
\end{array}$ \\
\hline $\begin{array}{l}\text { Режим варки } \\
\text { Гидромодуль } \\
\text { Продолжительность процесса, мин: } \\
\text { - подъем температуры } \\
\text { от } 15 \text { до } 115^{\circ} \mathrm{C} \\
\quad \text { пропитка при температуре } 115^{\circ} \mathrm{C} \\
\text { - подъем температуры до конечной } \\
135^{\circ} \mathrm{C} \\
\text { - варка при конечной температуре } \\
135^{\circ} \mathrm{C} \\
\text { Общая продолжительность варки, мин }\end{array}$ & $\begin{array}{c}50 \\
130 \\
\\
120 \\
\\
70 \\
370\end{array}$ & $\begin{array}{l}\text { Фракционирование целлюлозы: } \\
\text { - отделение мелкого волокна, \% } \\
\text { - выход сортированной целлюлозы } \\
\text { (с учетом отделения мелкого во- } \\
\text { локна), \% } \\
\text { Показатели целлюлозы: } \\
\text { Степень провара, п.ед. } \\
\text { Вязкость 1\%-ного медно-аммиачного } \\
\text { раствора целлюлозы, мПа·с } \\
\text { Массовая доля в целлюлозе, \%: } \\
\text { - смол и жиров } \\
\text { - лигнина }\end{array}$ & $\begin{array}{c}46,4 \\
60 \\
105 \\
1,55 \\
1,52\end{array}$ \\
\hline
\end{tabular}

Примечание: приведены средние величины результатов 5 варок.

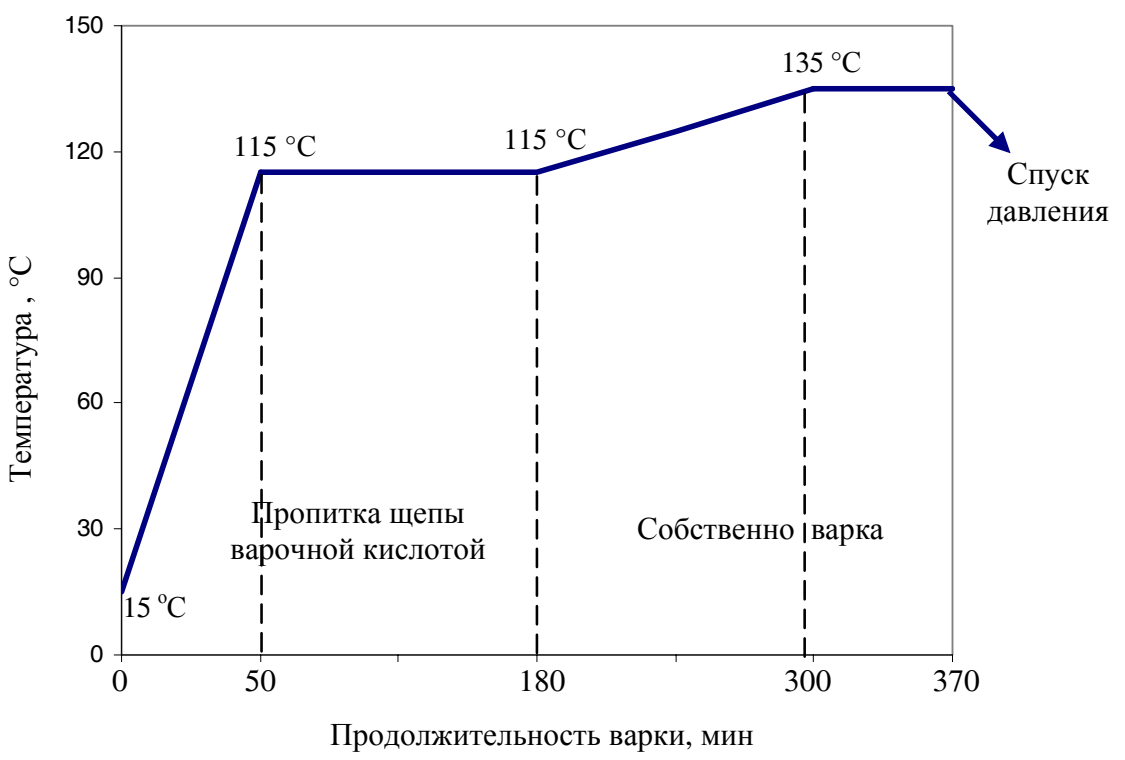

Рис. 1. График варки еловой целлюлозы для химической переработки 
Состав варочной кислоты и продолжительность варки приняты с целью получения целлюлозы глубокой степени провара с низким содержанием лигнина при максимальном сохранении углеводной части древесины. Таким результатам удовлетворяют мягкие условия варки невысокая температура и большая продолжительность процесса, полученные в наших предварительных исследованиях и приведенные в табл. 1 и на рис. 1.

Из данных табл. 1 следует, что варками при приведенных условиях получена целлюлоза весьма глубокой степени провара (жесткостью 60 перманганатных единиц - п.ед.), как это принято при получении целлюлозы для химической переработки. Выход целлюлозы (общий 49 \%, после отделения мелкого волокна 46,4 \%) свидетельствует о довольно мягких условиях варки, т.е. без значительной гидролитической деструкции целлюлозы. Подтверждается это и величиной вязкости полученной целлюлозы.

Отделение мелкого волокна от небеленой целлюлозы - обязательная операция при получении целлюлозы для химической переработки. Мелкие волокна повышают молекулярную неоднородность целлюлозы. Кроме того, в них сосредоточено основное количество экстрактивных веществ, содержание которых в целлюлозе для химической переработки ограничено.

В нашем случае массовая доля смол и жиров обычная для сульфитной целлюлозы. Массовая доля лигнина соответствует степени провара целлюлозы.

Получение целлюлозы для химической переработки, например для нитрования, из небеленой целлюлозы включает две основные стадии - делигнификацию небеленой целлюлозы и горячее щелочное облагораживание.

TCF-технология получения целлюлозы предполагает исключение хлора и хлорсодержащих реагентов и использование для делигнификации и отбелки целлюлозы окислительных реагентов - кислорода, озона, пероксида водорода. Использование кислорода и озона при отбелке целлюлозы по ТCF-схеме значительно усложняет технологию.

В связи с этим большой интерес представляет использование в качестве делигнифицирующего и отбеливающего реагента одного окислительного реагента - пероксида водорода, который обладает делигнифицирующими свойствами в щелочной и кислой среде, причем второй вариант более результативен. Эффективность делигнификации целлюлозы пероксидом водорода в кислой среде убедительно показана в результатах наших исследований по делигнификации и отбелке сульфатной целлюлозы [19].

Нами была поставлена весьма сложная задача - разработать схему отбелки целлюлозы для химической переработки без озона и кислорода по ТCF-технологии с использованием только одного окислительного реагента - пероксида водорода.

Исходя из изложенного и с учетом результатов предварительных исследований по отбелке сульфитной целлюлозы нами принята следующая короткая схема отбелки и облагораживания сульфитной целлюлозы для химической переработки: Пк - Щ - Пк 2 ГО - К, где Пк и Пк 2 - две ступени обработки целлюлозы пероксидом водорода в кислой среде, Щ - обработка щелочью между ступенями пероксидной обработки, ГО - горячее облагораживание, К - кисловка целлюлозы. После каждой ступени (за исключением кисловки) обязательна промывка целлюлозы (в схеме обозначена тире).

Принципиальная технологическая схема отбелки по указанной технологии приведена на рис. 2, условия отдельных ступеней обработки целлюлозы при отбелке и облагораживании в табл. 2.

В работе в качестве делигнифицирующих ступеней отбелки целлюлозы принята двухступенчатая обработка целлюлозы пероксидом водорода в кислой среде с промежуточной обработкой целлюлозы щелочным раствором (Пк - Щ - Пк 2 ). На ступенях делигнификации, кроме пероксида водорода, используется серная кислота (для подкисления раствора перокисда водорода) и катализатор, так как процесс делигнификации пероксидом водорода катализируемый. В качестве катализатора принят молибдат натрия. 

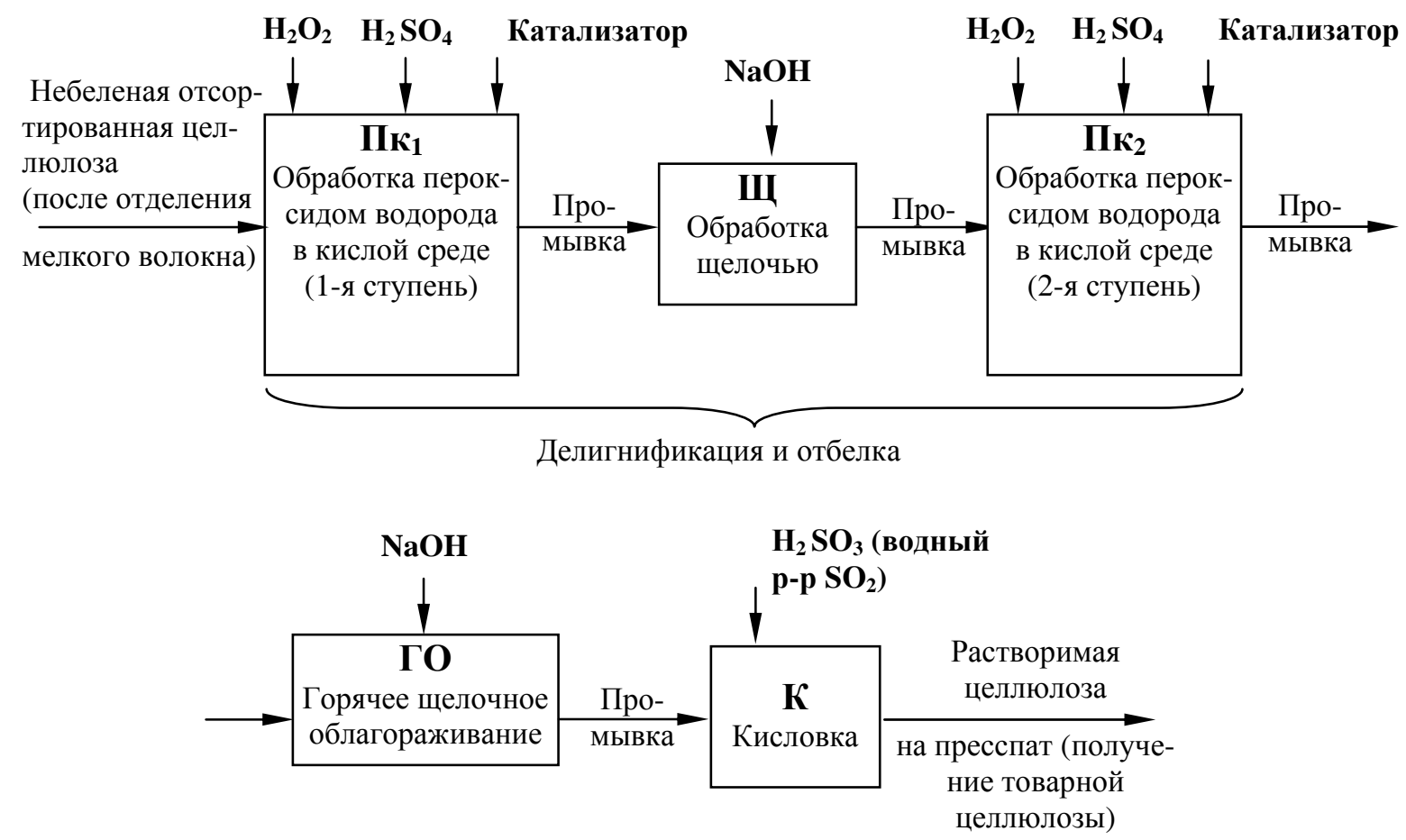

Рис. 2. Схема отбелки и облагораживания сульфитной еловой целлюлозы с получением растворимой целлюлозы

Таблица 2

Оптимальные условия отдельных ступеней обработки целлюлозы

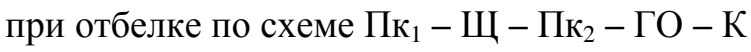

\begin{tabular}{|c|c|c|c|c|c|}
\hline \multirow{2}{*}{ Условия отбелки } & \multicolumn{5}{|c|}{ Ступень отбелки } \\
\hline & Пк ${ }_{1}$ & Щ & Пк 2 & $\Gamma \mathrm{O}$ & $\mathrm{K}$ \\
\hline $\begin{array}{l}\text { Расход реагентов, \% от абс. сух } \\
\text { целлюлозы: } \\
\text { - пероксида водорода } \\
\text { - серной кислоты } \\
\text { - катализатора } \\
\text { гидроксида натрия }\end{array}$ & $\begin{array}{c}2,5 \\
0,5 \\
0,3 \\
-\end{array}$ & $\begin{array}{c}- \\
- \\
- \\
2,0\end{array}$ & $\begin{array}{c}1,5 \\
0,5 \\
0,3 \\
-\end{array}$ & $\begin{array}{c}- \\
- \\
- \\
12,0\end{array}$ & $\begin{array}{l}- \\
- \\
- \\
-\end{array}$ \\
\hline рН отбельной ванны & $3,3-3,5$ & $11,3-11,6$ & $3,3-3,5$ & - & $4,5-5,0$ \\
\hline Температура, ${ }^{\circ} \mathrm{C}$ & 70 & 60 & 70 & 110 & $15-20$ \\
\hline Продолжительность процесса, мин & 130 & 60 & 130 & 160 & 60 \\
\hline Концентрация массы, \% & 12 & 12 & 12 & 12 & 5 \\
\hline
\end{tabular}

Примечание: условия отбелки приняты по результатам предварительных исследований.

В принятых условиях обработки целлюлозы на ступенях Пк серная кислота выполняет две функции - регулирует кислотность среды в отбельной ванне и одновременно стабилизирует раствор пероксида водорода, уменьшая потери пероксида на побочную реакцию разложения и тем самым снижая расход его на отбелку. Таким образом, проявляется синергический эффект от совместного воздействия на процесс делигнификации серной кислоты и катализатора.

Щелочная обработка целлюлозы после ступени Пк является обязательной для удаления из целлюлозы продуктов реакции и остаточного реагента, т.е. (Пк - Щ) представляет собой одну ступень делигнификации целлюлозы. После второй ступени обработки пероксидом водорода в кислой среде щелочная обработка и щелочное облагораживание совмещены в схеме от- 
белки (Пк - ГО). Таким образом, получена бесхлорная короткая ТCF-схема отбелки и облагораживания целлюлозы.

В схеме реализован принцип чередования кислых и щелочных ступеней, который позволяет создать так называемый насосный эффект и интенсифицировать процесс отбелки благодаря набуханию волокна в щелочной среде и контракции в кислой [20].

В табл. 3 и для наглядности на рис. 3 представлены результаты изменения физикохимических показателей целлюлозы в процессе отбелки и облагораживания по схеме Пк $\kappa_{1}-Щ-\Pi \kappa_{2}-\Gamma \mathrm{O}-\mathrm{K}$.

Таблица 3

Изменение физико-химических показателей целлюлозы в процессе отбелки по схеме Пк - Щ - Пк 2 - ГО - К

\begin{tabular}{|c|c|c|c|c|c|c|}
\hline \multirow[b]{2}{*}{ Показатель целлюлозы } & \multirow{2}{*}{$\begin{array}{c}\text { Небеле- } \\
\text { ная цел- } \\
\text { люлоза }\end{array}$} & \multicolumn{3}{|c|}{ Значения показателей } & \multirow{2}{*}{$\begin{array}{c}\text { Норма для дре- } \\
\text { весной сульфит- } \\
\text { ной целлюлозы } \\
\text { ЦА марки К }\end{array}$} & \multirow{2}{*}{$\begin{array}{c}\text { Метод } \\
\text { испытания }\end{array}$} \\
\hline & & Пк - Щ & Пк & $\Gamma \mathrm{O}-\mathrm{K}$ & & \\
\hline $\begin{array}{c}\text { Выход беленой целлюлозы, \%: } \\
\text { - от небеленой целлюлозы } \\
\text { - древесины }\end{array}$ & - & $\begin{array}{l}96,8 \\
46,5\end{array}$ & $\begin{array}{l}94,6 \\
45,4 \\
\end{array}$ & $\begin{array}{l}80,8 \\
38,8\end{array}$ & & \\
\hline $\begin{array}{l}\text { Показатель целлюлозы: } \\
\text { - степень провара (жесткость), } \\
\text { п.ед. } \\
\text { - вязкость } 1 \% \text {-ного медно- } \\
\text { аммиачного раствора целлю- } \\
\text { лозы, мПа·с }\end{array}$ & 105,0 & 66,3 & 42,0 & 46,5 & $30-55$ & По ГОСТ 14363.2 \\
\hline $\begin{array}{l}\text { Массовая доля в целлюлозе, \%: } \\
-\alpha \text {-целлюлозы }\end{array}$ & 88,5 & 84,7 & 84,3 & 94,5 & Не менее 93 & По ГОСТ 6840 \\
\hline - золы & 0,68 & 0,48 & 0,27 & 0,13 & Не более 0,16 & По ГОСТ 18461 \\
\hline - лигнина & 1,52 & 0,91 & 0,42 & 0,28 & Не более 0,4 & $\begin{array}{c}\text { По методике } \\
\text { источника [21] }\end{array}$ \\
\hline - смол и жиров & 1,62 & 1,20 & 1,18 & 0,35 & Не более 0,5 & По ГОСТ 6841 \\
\hline Степень делигнификации, \% & - & 40,1 & 73,0 & 82,5 & & \\
\hline Обессмоливание целлюлозы, \% & - & 26,1 & 27,2 & 78,5 & & \\
\hline
\end{tabular}

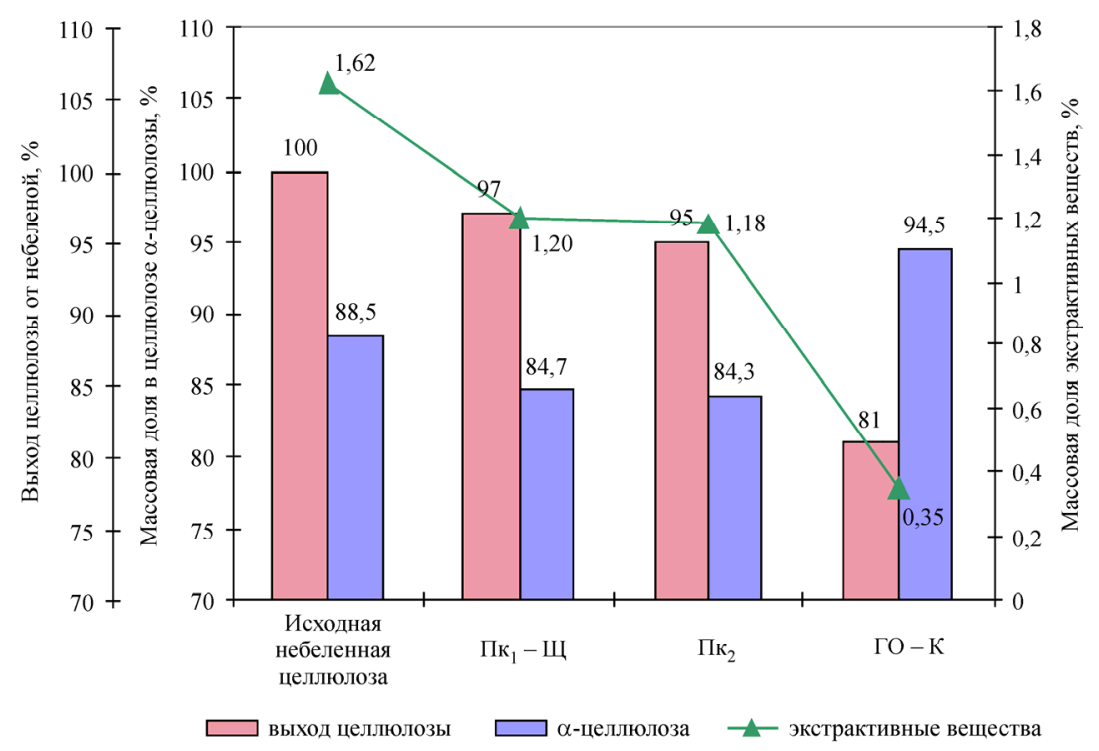

Рис. 3. Графики изменения основных показателей целлюлозы в процессе отбелки по схеме Пк - Щ - Пк $\kappa_{2}-Г О-К$ 
Как следует из приведенных результатов отбелки и облагораживания, на делигнифицирующих ступенях (Пк - Щ - Пк 2 ) потери волокна в результате окислительной деструкции целлюлозы составили 5,4 \%, что свидетельствует о довольно мягких условиях обработки на ступенях делигнификации и о весьма средней степени деградации углеводной части целлюлозы.

При получении целлюлозы для химической переработки ступень облагораживания традиционно связана с большими потерями волокна (до 20-25 \%). Задача облагораживания состоит в удалении из целлюлозы большей части гемицеллюлоз и ее низкомолекулярной фракции.

В результате облагораживания массовая доля $\alpha$-целлюлозы в целлюлозе составила $94,5 \%$, потери целлюлозы - $14 \%$, из которых примерно $1 \%$ приходится на лигнин и экстрактивные вещества (смолы и жиры).

Большая часть лигнина (73\%) удалена из целлюлозы, естественно, на ступенях делигнификации. Однако при получении растворимой целлюлозы из сульфитной еще часть лигнина $(\sim 10 \%)$ перешла в щелок на ступени облагораживания и в растворимой целлюлозе осталось всего 0,28 \% лигнина.

Экстрактивные вещества (смолы и жиры) удаляются из целлюлозы главным образом на щелочных ступенях отбелки: $26 \%$ на ступени щелочения и более 50 \% на ступени облагораживания. Обессмоливание целлюлозы - весьма важный результат процессов отбелки и облагораживания. Это трудно решаемая задача отбелки целлюлозы. В нашем случае обессмоливание целлюлозы составило 78 \%. Нам удалось получить целлюлозу с массовой долей смол и жиров $0,35 \%$.

Массовая доля золы в целлюлозе снижается обычно в процессе ее промывки и на кислых ступенях ее обработки; в беленой целлюлозе содержание ее невелико - 0,13\%.

Важнейшим показателем качества целлюлозы для химической переработки является вязкость ее растворов (в нашем случае вязкость $1 \%$-ного медно-аммиачного раствора целлюлозы). Показатель вязкости целлюлозы на ступенях делигнификации существенно снижается в результате окислительной деградации целлюлозы. В результате облагораживания целлюлозы вязкость повышается за счет удаления из нее гемицеллюлоз и низкомолекулярных фракций.

Получение целлюлозы с величинами вязкости в пределах требований к целлюлозе для химической переработки - задача сложная. Нам удалось получить целлюлозу необходимой вязкости - в интервале 30-55 мПа·с.

В результате исследований получена растворимая целлюлоза для химической переработки с показателями качества, полностью соответствующими техническим показателям целлюлозы древесной сульфитной ЦА марки К [22].

\section{Выводы}

1. Разработаны условия сульфитной варки еловой щепы с получением небеленой целлюлозы, предназначенной для получения (после отбелки и облагораживания) целлюлозы для химической переработки.

2. Разработана новая короткая схема отбелки и облагораживания сульфитной целлюлозы для химической переработки по экологичной ТCF-технологии с использованием для делигнификации и отбелки одного окислительного реагента - пероксида водорода.

3. Разработаны оптимальные условия каждой ступени обработки целлюлозы при отбелке

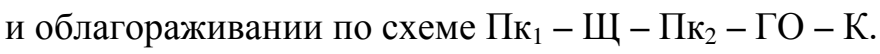

4. В результате исследований получена еловая сульфитная беленая и облагороженная целлюлоза, все показатели качества которой соответствуют техническим показателям целлюлозы древесной сульфитной ЦА марки К. 


\section{Библиографический список}

1. Модификация целлюлозы - перспективное направление в создании новых материалов / Н.И. Ткачева, С.В. Морозов, И.А. Григорьев, Д.М. Могнонов, Н.А. Колчанов // Высокомолекулярные соединения. - 2013. - Серия Б, т. 55, № 8. - С. 1086-1107.

2. Медведева С.А., Тимофеева С.С. Биотехнологии для повышения экологической безопасности целлюлозно-бумажной промышленности (современное состояние) // Безопасность в техносфере. - 2013. T. 2, № 3. - C. 28-34.

3. Иванов С.Н. Технология бумаги. - 3-е изд. - М.: Школа бумаги, 2006. - 696 с.

4. Новожилов Е.В., Пошина Д.Н. Биотехнологии в производстве целлюлозы для химической переработки (обзор) // Химия растительного сырья. - 2011. - № 3. - С. 15-32.

5. Хакимова Ф.Х., Ковтун Т.Н. Отбелка целлюлозы: учеб. пособие. - Пермь: Изд-во Перм. гос. техн. ун-та, 2010. - 182 с.

6. Непенин Н.Н. Технология целлюлозы: в 3 т. Т. І. Производство сульфитной целлюлозы / под ред. д-ра техн. наук Ю.Н. Непенина. - 2-е изд., перераб. - М.: Лесная промышленность, 1976. - 624 с.

7. Высококачественная целлюлоза из волокна пеньки и управление процессом ее получения / 3.Т. Валишина, А.Е. Голубев, Н.Г. Ибрагимов, А.В. Косточко // Вестник технологического университета. -2015 . - T. 18, № 24. - С. 77-81.

8. Рогова Н.С., Гараева М.Р., Шипина О.Т. Нитраты целлюлозы из промышленных и бытовых отходов // Вестник Казанского технологического университета. - 2010. - № 9. - С. 131-135.

9. Якушева А.А. Нитраты целлюлозы: современное состояние за рубежом // Технологии и оборудование химической, биотехнологической и пищевой промышленности: сб. материалов VI Всерос. науч.практ. конф. студ., асп. и мол. ученых с междунар. участием / Бийский технологический институт (филиал ФГБОУ ВПО «Алтайский государственный технический университет»). - Бийск, 2013. - С. 139-141.

10. Технология целлюлозно-бумажного производства: справ. материалы: в 3 т. Т. III. Автоматизация, стандартизация, экономика и охрана окружающей среды. Ч. 3. Наилучшие доступные технологии в целлюлозно-бумажной промышленности. - СПб.: Политехника, 2012. - 294 с.

11. Поиск возобновляемых источников целлюлозы для многоцелевого использования / В.К. Шумный, Н.А. Колчанов, Г.В. Сакович, В.Н. Пармон, С.Г. Вепрев, Н.Н. Нечипоренко, Т.Н. Горячковская, А.В. Брянская, В.В. Будаева, А.В. Железнов, Н.Б. Железнова, В.Н. Золотухин, Р.Ю. Митрофанов, А.С. Розанов, К.Н. Сорокина, Н.М. Слынько, В.А. Яковлев, С.Е. Пельтек // Информационный вестник ВОГиС. - 2010. - Т. 14, № 3. - С. 569-577.

12. Шпаков Ф.В., Неволин В.Ф. Основные направления совершенствования технологии производства беленых полуфабрикатов в России на пороге XXI века // PAP-FOR 98: науч.-техн. конф. - CПб., 1998. - C. 74-79.

13. Сергеев А.Д., Атьман О.П., Сергеева И.В. Технико-экономическое и экологическое обоснование выбора оптимальных технологий ЕСF отбелки хвойной и лиственной целлюлозы // Целлюлоза. Бумага. Картон. - 2008. - № 2. - С. 58-62.

14. Промывка и отбелка целлюлозы: учеб. пособие. / Л.А. Миловидова [и др.].- Архангельск, 2013. - 212 c.

15. Steffes F., Germgard U. ECF, TCF upgrade choices key on world market // Pulp \& Paper. - 1995. № 6. - P. 83-92.

16. Способ отбелки сульфатной целлюлозы: пат. 2445415 Рос. Федерация, МИК ${ }^{7}$ D21C9/10 / Хакимова Ф.Х., Ковтун Т.Н., Синяев К.А., Носкова О.А.; заявитель и патентообл. Перм. гос. техн. ун-т. № 2010147248/12; заявл. 18.11.10, опубл. 20.03.12, Бюл. № 8. - 3 с.

17. Полютов А.А., Пен Р.З., Бывшев А.В. Технология целлюлозы. Экологически чистое производство: учеб. пособие. - Красноярск: Краснояр. писатель, 2012. - 294 с.

18. Парен А., Яакара Й. Использование пероксомолибдата при ЕСF-отбелке сульфатной целлюлозы // Целлюлоза. Бумага. Картон. - 1999. - № 1-2. - С. 20-23.

19. Хакимова Ф.Х., Синяев К.А. Отбелка сульфатной целлюлозы пероксидом водорода и хлоритом натрия // Химия растительного сырья. - 2013. - № 2. - С. 57-62.

20. Аким Г.Л. Бесхлорная отбелка целлюлозы // Целлюлоза. Бумага. Картон. - 2001. - № 5-6. C. 24-28.

21. Оболенская А.В., Ельницкая 3.П., Леонович А.А. Лабораторные работы по химии древесины и целлюлозы: учеб. пособие для вузов. - М.: Экология, 1991. - 320 с. 
22. Жегров Е.Ф., Милехин Ю.М., Берковская Е.В. Химия и технология баллиститных порохов, твердых ракетных и специальных топлив. Т. 2. Технология / РИЦ МГУП им. И. Федорова. - М., 2011. $551 \mathrm{c}$.

\section{References}

1. Tkacheva N.I., Morozov S.V., Grigor'yev I.A., Mognonov D.M., Kolchanov N.A. Modifikatsiya tsellyulozy - perspektivnoye napravleniye v sozdanii novykh materialov [Cellulose modification - the perspective direction in creation of new materials]. Polymer Science, series B, 2013, vol. 55, no. 8, pp.1086-1107.

2. Medvedeva S.A., Timofeyeva S.S. Biotekhnologii dlya povysheniya ekologicheskoy bezopasnosti tsellyulozno-bumazhnoy promyshlennosti (sovremennoye sostoyaniye) [Biotechnologies for increase in environmental safety of pulp and paper industry (current state)]. Bezopasnost v texnosfere, 2013, vol. 2, no. 3, pp. $28-34$.

3. Ivanov S.N. Tekhnologiya bumagi. [Tekhnologiya of paper, 3rd ed.]. Moscow: Shkola bumagi, 2006, $696 \mathrm{p}$.

4. Novozhilov E.V., Poshina D.N. Biotekhnologii v proizvodstve tsellyulozy dlya khimicheskoy pererabotki (obzor) [Biotechnologies in production of cellulose for chemical processing (review)]. Khimija rastitel'nogo syr'ja ("Chemistry of plant raw material"), 2011, no. 3, pp. 15-32.

5. Khakimova F.KH., Kovtun T.N. Otbelka tsellyulozy: ucheb. posobiye [Cellulose bleaching]. Perm: Perm State Technical University, 2010, 182 p.

6. Nepenin N.N. Tekhnologiya tsellyulozy. Proizvodstvo sulfitnoy tsellyulozy [Production of sulphitic cellulose]. Moscow: Lesnaya promyshlennost, 1976, vol. I, 624 p.

7. Valishina Z.T., Golubev A.E., Ibragimov N.G., Kostochko A.V. Vysokokachestvennaya tsellyuloza iz volokna pen'ki i upravleniye protsessom eye polucheniya [High-quality cellulose from fiber of hemp and management of process of its receiving]. Bulletin of the Technological University, 2015, vol. 18, no. 24, pp. 77-81.

8. N.S. Rogova, M.R.Garaeva, O.T. Shipina. Nitraty`cellyulozy`iz promy`shlenny`x i by`tovy`x otxodov [Cellulose nitrates from industrial and household waste] // Vestnik Kazanskogo texnologicheskogo universiteta. 2010, no. 9, pp. 131-135.

9. Yakusheva A.A. Nitraty tsellyulozy: sovremennoye sostoyaniye za rubezhom [Cellulose nitrates: the current state abroad]. Proceedings of VI All-Russia Scientific and Practical Conference of Students, Postgraduates and Young Scientists with International Participation «Tekhnologii i oborudovaniye khimicheskoy, biotekhnologicheskoy i pishchevoy promyshlennosti». Altai State Technical University, 2013, pp. 139-141.

10. Tekhnologiya tsellyulozno-bumazhnogo proizvodstva [The technology of pulp and paper production]. St.Petersburg, Politehnika, 2012, vol. III, part. 3, 294 p.

11. Shumnyy V.K., Kolchanov N.A., Sakovich G.V. and all. Poisk vozobnovlyayemykh istochnikov tsellyulozy dlya mnogotselevogo ispol'zovaniya [Search of renewable sources of cellulose for multi-purpose use]. Russian Journal of Genetics: Applied Research, 2010, Vol. 14, No. 3, pp.569-577.

12. Shpakov F.V. Osnovnyye napravleniya sovershenstvovaniya tekhnologii proizvodstva belenykh polufabrikatov $v$ Rossii na poroge XXI veka [The main directions of perfecting of the production technology of bleached semi-finished products in Russia on the XXI century threshold]. Proceedings of Scientific Conference RAR-FOR 98, St.petersburg, 1998, pp. 74-79.

13. Sergeev A.D., Atman O.P., Sergeeva I.V. Tekhniko-ekonomicheskoye i ekologicheskoye obosnovaniye vybora optimalnykh tekhnologiy ECF otbelki khvoynoy i listvennoy tsellyulozy [Technical and economic and ecological justification of the choice of optimum ECF technologies of a bleaching of coniferous and deciduous cellulose]. Tsellyuloza. Bumaga. Karton, 2008, no. 2, pp. 58-62.

14. Milovidova L.A. Promyvka i otbelka tsellyulozy: ucheb. posobiye. [Washing and bleaching of cellulose]. Arxangelsk: Northern (Arctic) Federal University named after M.V. Lomonosov, 2013, 212 p.

15. Steffes F., Germgard U. ECF, TCF upgrade choices key on world market. Pulp \& Paper, 1995, No. 6, pp. 83-92.

16. KHakimova F.Kh., Kovtun T.N., Sinyayev K.A., Noskova O.A. Sposob otbelki sulfatnoy tsellyulozy [Way of a bleaching of sulphatic cellulose]. Patent 2445415 (RF), 2012, no. 8.

17. Polyutov A.A., Pen R.Z., Byvshev A.V. Tekhnologiya tsellyulozy. Ekologicheski chistoye proizvodstvo: ucheb. posobiye [Pulp technology. Environmentally friendly production]. Krasnoyarsk, 2012, 294 p.

18. Paren A., Yaakara Y. Ispolzovaniye peroksomolibdata pri ECF-otbelke sulfatnoy tsellyulozy [Use of peroxomolybdate at an ECF bleaching of sulphatic cellulose]. Tsellyuloza. Bumaga. Karton, 1999, no. 1-2, pp. 20-23. 
19. Khakimova F.Kh., Sinyayev K.A. Otbelka sulfatnoy tsellyulozy peroksidom vodoroda i khloritom natriya [Bleaching of sulphatic cellulose hydrogen peroxide and chlorite of sodium]. Khimija rastitel'nogo syr'ja ("Chemistry of plant raw material"), 2013, no. 2, pp. 57-62.

20. Akim G.L. Beskhlornaya otbelka tsellyulozy [Non-chlorine bleaching of cellulose]. Cellyuloza. Bumaga. Karton. 2001, no. 5-6, pp. 24-28.

21. Obolenskaya A.V., Elnitskaya Z.P., Leonovich A.A. Laboratornyye raboty po khimii drevesiny i tsellyulozy: Uchebnoye posobiye dlya vuzov [Laboratory work on the chemistry of wood and pulp: A manual for universities]. Moscow: Ekologiya, 1991, 320 p.

22. Zhegrov E.F., Milekhin Yu.M., Berkovskaya E.V. Khimiya i tekhnologiya ballistitnykh porokhov, tverdykh raketnykh i spetsialnykh topliv [Chemistry and technology of ballistitny gunpowder, solid rocket and special fuels]. Moscow: Moscow State University of Printing Arts, 2011, vol. 2, 551 p.

\section{Об авторах}

Хакимова Фирдавес Харисовна (Пермь, Россия) - доктор технических наук, профессор, заслуженный работник Высшей школы, профессор кафедры «Технологии полимерных материалов и порохов» ФГБОУ ВО ПНИПУ (614990, г. Пермь, Комсомольский пр., д. 29; e-mail: tcbp@ pstu.ru).

Носкова Ольга Алексеевна (Пермь, Россия) - кандидат технических наук, доцент кафедры «Химические технологии» ФГБОУ ВО ПНИПУ (614990, г. Пермь, Комсомольский пр., д. 29; e-mail: oa-noskova@mail.ru).

Котельников Сергей Александрович (Пермь, Россия) - кандидат технических наук, доцент кафедры «Технологии полимерных материалов и порохов» ФГБОУ ВО ПНИПУ (614990, г. Пермь, Комсомольский пр., д. 29; e-mail: ksa76@mail.ru).

Синяев Константин Андреевич (Пермь, Россия) - кандидат технических наук, доцент кафедры «Химические технологии» ФГБОУ ВО ПНИПУ (614990, г. Пермь, Комсомольский пр., д. 29; е-mail: sinyaev83@mail.ru).

\section{About the authors}

Firdaves H. Hakimova (Perm, Russian Federation) - Doctor of Technical Sciences, Professor, Honourable Worker of the Higher School of Technology of Polymeric Materials and Powder Department, Perm National Research Polytechnic University (29, Komsomolsky av., Perm, 614990, Russian Federation; e-mail: tcbp@pstu.ru).

Olga A. Noskova (Perm, Russian Federation) - CSc in Technical Sciences, Associate Professor of Chemical Technologies Department, Perm National Research Polytechnic University (29, Komsomolsky av., Perm, 614990, Russian Federation; e-mail: oa-noskova@mail.ru).

Sergey A. Kotelnikov (Perm, Russian Federation) - CSc in Technical Sciences, Associate Professor of Technology of Polymeric Materials and Powders Department, Perm National Research Polytechnic University (29, Komsomolsky av., Perm, 614990, Russian Federation; e-mail: ksa76@mail.ru ).

Konstantin A. Sinyaev (Perm, Russian Federation) - CSc in Technical Sciences, Associate Professor of Chemical Technologies Department, Perm National Research Polytechnic University (29, Komsomolsky av., Perm, 614990, Russian Federation; e-mail: sinyaev83@mail.ru). 